\title{
A twofold increase in BRCA mutation related prostate cancer among Ashkenazi Israelis is not associated with distinctive histopathology
}

\author{
R M Giusti, J L Rutter, P H Duray, L S Freedman, M Konichezky, J Fisher-Fischbein, M H Greene, \\ B Maslansky, A Fischbein, S B Gruber, G Rennert, R D Ronchetti, S M Hewitt, J P'Struewing, \\ J Iscovich
}

J Med Genet 2003;40:787-792

T he magnitude of the risk of prostate cancer among Ashkenazi Jewish carriers of the common mutations in the BRCA1 and BRCA2 genes, the so-called Ashkenazi $B R C A$ founder mutations (BRCA1 185delAG and 5382insC, and BRCA2 6174delT), remains uncertain. Two large epidemiological studies have suggested that the cumulative incidence of prostate cancer among male first degree relatives of individuals with a founder mutation may approach $30 \%$ by 80 years of age. ${ }^{2}$ Smaller clinical studies have, in general, not demonstrated an increased frequency of founder mutations among Jewish men with prostate cancer..$^{3-6}$ Only one study to date has examined clinical characteristics of prostate cancer patients with founder mutations. ${ }^{3}$ In this study, the three BRCA associated tumours that were identified appeared to be associated with biologically more aggressive disease, presenting with higher PSA levels, higher Gleason scores and more advanced stage at diagnosis, than did prostate cancers diagnosed in men without mutations.

Founder BRCA mutations occur in more than $2 \%$ of Ashkenazi Jews. ${ }^{178}$ Thus, an increased risk of prostate cancer among BRCA carriers, or an aggressive phenotype in $B R C A$ associated prostate cancers, could constitute a significant cancer burden in this group, and would have substantial management implications for male carriers of Ashkenazi founder mutations.

We undertook the current study to obtain a more stable estimate of the Ashkenazi founder mutation rate among Jewish men diagnosed with prostate cancer, and to determine if prostate cancer occurring in carriers of the common Ashkenazi BRCAl or BRCA2 mutations is associated with distinctive pathological or clinical features. The precedent for this hypothesis is best illustrated by the hereditary renal cancer syndromes, in which recognising specific histological subsets of subjects has facilitated the identification of genetically distinct disorders. ${ }^{9} 10$

All men newly diagnosed with prostate cancer were identified at sixteen of the 23 hospital based and reference pathology laboratories that provided histological diagnosis of prostate cancer in Israel from 1994 to 1995. This time period was selected because it antedated the widespread use of prostate specific antigen (PSA) screening in Israel. One laboratory declined participation, and a second had no Ashkenazi cases during the period of interest. To represent the remaining five small laboratories, a larger centre, which drew its cases from the same geographic region, was selected for study. Only half of the cases diagnosed at one large reference laboratory were enrolled, by selecting all cases diagnosed at that facility every other month. Each pathology report was reviewed to verify the diagnosis of prostate cancer,

\section{Key points}

- To estimate the risk of prostate cancer $(\operatorname{PrC})$ associated with the common Ashkenazi founder mutations of the $B R C A 1$ and BRCA2 genes, and to investigate the histopathology characteristics of mutation related $\operatorname{PrC}$, we identified 979 Ashkenazi Jewish men diagnosed with $\operatorname{PrC}$ during 1994-1995 in 16 Israeli hospitals and reference laboratories.

- DNA obtained from paraffin sections was tested for the three founder mutations in $940(96 \%)$ cases, and a mutation was identified in $30 / 940(3.2 \%)$, a two fold increase compared with a referent group of Ashkenazi men over 50 years old with no history of prostate cancer (21 of $1344(1.6 \%) ; \mathrm{OR}=2.1 ; 95 \% \mathrm{Cl}=1.2-3.6)$.

- In the entire cohort, no difference was found in the mean age at diagnosis between cases with and without a founder mutation.

- A representative histology slide was blindly reviewed from 29/30 (97\%) of Israeli BRCA associated PrC cases and 145 individually matched non-carrier $\mathrm{PrC}$ cases.

- No differences were noted between the two sets of cases regarding: the mean Gleason score; presence of prostatic intraepithelial neoplasia or atypical adenomatous hyperplasia; or other histopathology features.

- These results are consistent with a doubling of the risk of $\operatorname{PrC}$ among carriers of an Ashkenazi BRCA founder mutation, and do not suggest that mutation related $\operatorname{PrC}$ is characterised by early age at diagnosis or distinct histopathology features.

and to exclude cases with a previous diagnosis of prostate cancer.

All identified prostate cancer subjects were matched to the Israeli Population Registry. Patients were considered to be of Ashkenazi heritage if they were born in Europe or the United States or, if Israeli born, if both parents were born in Europe or the United States. The diagnostic pathology block was retrieved from Ashkenazi prostate cancer cases when available. Minimal information on cases was retained prior to sample anonymisation including: age at diagnosis, hospital of registration, tissue acquisition method (core biopsy, prostatectomy, or transuretheral resection of the prostate).

Abbreviations: PSA, prostate specific antigen 
Participants were then assigned a unique study identifier linked to the pathology specimens. The pathology material was anonymised prior to pathology review and data analysis. Due to the anonymous nature of the study design, medical records were not abstracted, and no information concerning stage or PSA levels at the time of diagnosis was obtained. The study was done under a waiver of the requirement for Institutional Review Board review granted by the National Institutes of Health Office of Human Subjects Research.

We estimated the population founder mutation carrier frequency in Ashkenazi men over 50 years old using data from two study populations: (a) Ashkenazi Jewish male volunteers with no personal history of prostate cancer in the Washington Ashkenazi Study (WAS) (Struewing et al ${ }^{1}$ and $\mathrm{J}$ Struewing, unpublished data), and ( $b$ ) Israeli men enrolled in the Molecular Epidemiology of Colorectal Cancer (MECC) study, an Israeli case-control study with phenotype and genotype data available for 901 population based controls (Gruber et $a l^{11}$ and S Gruber and G Rennert, unpublished data). Controls were individually matched by sex, year of birth, and clinic to incident cases of colorectal cancer diagnosed in northern Israel between March 1998 and December 2002. ${ }^{11}$

For the pathology review, each prostate cancer case identified as positive for one of the three Ashkenazi founder mutations was matched to five non-carrier prostate cancer cases by tissue acquisition procedure (core needle biopsy, transuretheral resection of the prostate, or prostatectomy). The best available match for each carrier case was made using a four tiered system: $(a)$ an exact match by age and pathology laboratory; $(b)$ the closest age match (within 5 years) from the same pathology laboratory; (c) the closest age match (within 5 years) from the same type of laboratory (hospital based or referral laboratory); or $(d)$ the closest age match (within 3 years) from any laboratory type. To select five controls per case, we first selected one control per case, selecting a control from the most optimal tier. A second control for each case was then selected, and so forth. Controls were selected without replacement. Thus, once a control was selected as a match for a case, it was unavailable for selection for another case. Histology slides from carrier and non-carrier cases were randomly arranged, and reviewed by a single pathologist (PD), who was blinded to the mutation status of the cases.

Unstained $5 \mu \mathrm{m}$ paraffin sections were treated with xylene, rehydrated, and digested with proteinase $\mathrm{K}$, followed by phenol extraction and ethanol precipitation. Using $2-4 \mu \mathrm{l}$ of the sample, a multiplex PCR was performed to detect the three founder mutations, as described previously. ${ }^{12}$

Mutation rates were estimated as simple proportions. These rates were compared with the expected rates in controls using the $\chi^{2}$ test with Yates' continuity correction. An extended McNemar test was employed to compare binary outcomes in mutation related cases with their matched controls. Here, $k_{i}=$ number of controls in matched set $i$, $x_{i}=$ case result $(0$ or 1$)$ in matched set $i, m_{i}=$ number of controls in matched set $\mathrm{i}$ with positive result (equal to 1 ) and $\mathrm{n}=$ number of matched sets (equal to 27 in our study). The estimate of the odds ratio was obtained from the sum of $x_{i}$ $\left(\mathrm{k}_{\mathrm{i}}-\mathrm{m}_{\mathrm{i}}\right)$ over each matched set divided by the sum of $\mathrm{m}_{\mathrm{i}}\left(1-\mathrm{x}_{\mathrm{i}}\right)$. To test whether the odds ratio was different from 1 , for each matched set the observed minus the expected value of $\mathrm{x},\left(\mathrm{O}_{\mathrm{i}}-\mathrm{E}_{\mathrm{i}}\right)$ was equal to

$$
x_{i}-\left(m+x_{i}\right) /\left(k_{i}+1\right),
$$

and its variance, $\mathrm{V}_{\mathrm{i}}$ was equal to

$$
\left(m_{i}+x_{i}\right)\left(k_{i}+1-m_{i}-x_{i}\right) /\left(k_{i}+1\right)^{2} .
$$

The sum of $\mathrm{O}_{\mathrm{i}}-\mathrm{E}_{\mathrm{i}}$ over all matched sets was denoted by $\mathrm{O}-\mathrm{E}$, and the sum of $\mathrm{V}_{\mathrm{i}}$ over all matched sets by $\mathrm{V}$. The test statistic was then calculated as $(\mathrm{O}-\mathrm{E})^{2} / \mathrm{V}$. Because of the small sample size in the case-control study, the usual $\chi^{2}$ approximation did not provide a reliable reference distribution for this statistic under the null hypothesis. We therefore estimated the $\mathrm{p}$ value and confidence limits for the odds ratio by Monte Carlo simulation, using runs of 10000 simulations.

To compare ordered outcomes, such as Gleason's grade, between carriers and their matched controls, the stratified Wilcoxon test was used as the test statistic ${ }^{13}$ and, again, the $p$ values and confidence limits for the difference in mean tumor grade were estimated from runs of 10000 Monte Carlo simulations. A three way test for the difference in the least squared mean age at diagnosis was performed among BRCAl positive, BRCA2 positive and mutation negative men, using SAS PROC GLM (SAS Institute Inc., Carry, NC, USA). Associations with $\mathrm{p}<0.05$ were considered to be significant.

Among Ashkenazi men, 992 eligible cases of prostate cancer were identified, representing approximately two thirds of all prostate cancer cases diagnosed in Israel during the study period. In 13 cases ( $1 \%)$, no pathology material could be retrieved. In the remaining 979 cases, a haematoxylin and eosin stained slide was obtained for review, and five unstained $5 \mu \mathrm{m}$ paraffin fixed sections were obtained as the DNA source for mutation testing. DNA was extracted and mutation testing was successfully completed for all three of the founder BRCA mutations on 940 (96\%) of these cases.

In the entire cohort, although the BRCA2 related cases were slightly younger at diagnosis than the non-carriers and the $B R C A 1$ related cases, there were no statistical differences in the mean ages of these three groups (BRCA2 71.6 years, noncarriers 73.6 years, and BRCAI 74.2 years). One prostate cancer case, a non-carrier, was diagnosed at the age of 49 years. All other cases were diagnosed at 50 years of age or later. Among the prostate cancer cases, mutation carriers were more frequently diagnosed by core needle biopsy (29/30 $(93 \%) v 625 / 910(69 \%))$ than non-carriers. This difference in the mode of diagnostic tissue acquisition was significantly different between mutation carriers and non-carriers $\left(\chi^{2}=9.03, \mathrm{p}=.01\right)$.

The overall founder mutation prevalence among Israeli prostate cancer cases was 30/940 (3.2\%). Of these, 16 (1.7\%) had a BRCAl mutation [185delAG, 14 (1.5\%); 5382insC, 2 $(0.2 \%)]$ and $14(1.5 \%)$ had a BRCA2 6174delT mutation. In the WAS and MECC studies, the mutation frequencies found among Ashkenazi men over the age of 50 years with no history of prostate cancer were 1.49 and 1.69 respectively (table 1). The difference between these two frequencies was not statistically significant $(\mathrm{OR}=0.88 ; 95 \% \mathrm{CI}=0.3-2.3)$. When the two comparison groups were combined (WAS+MECC), the increased frequency of any of the founder mutations and of the BRCAl 185delAG founder mutation among Israeli $\operatorname{PrC}$ cases reached statistical significance (table 1).

Cases and controls in the pathology review were well matched. An exact match was found for $85 \%$ of the first selected controls and for $62 \%, 54 \%, 50 \%$ and $39 \%$ of the second to fifth controls, respectively. In only four cases was a fourth tier control selected for inclusion. One of the 30 identified mutation carriers (with a BRCAl 185delAG mutation) and his five matched controls were eliminated from the pathology case-control study, because the reviewing pathologist was not able to confirm the diagnosis of prostate cancer based on the limited material available for review. The remaining 29 confirmed prostate cancer cases with an identified BRCAI or BRCA2 founder mutation, and a total of 145 individually matched non-carrier cases constituted the pathology review group. 
Table 1 The frequency of BRCA1/2 Ashkenazi founder mutations among Israeli Ashkenazi men diagnosed with incident prostate cancer 1994-1995, and among men aged 50 years and over with no history of prostate cancer in the Washington Ashkenazi Study (WAS), and in the Molecular Epidemiology of Colorectal Cancer (MECC) study

\begin{tabular}{|c|c|c|c|c|c|}
\hline & \multicolumn{2}{|l|}{ BRCA1 (n (\%)) } & \multirow{2}{*}{$\begin{array}{l}\text { BRCA2 (n (\%)) } \\
6174 \text { delT }\end{array}$} & \multirow[b]{2}{*}{ Total positive } & \multirow[b]{2}{*}{ Total (n) } \\
\hline & 185delAG & 5382insC & & & \\
\hline Israeli Prostate Study & $14(1.49)$ & $2(0.21)$ & $14(1.49)$ & $30(3.19)$ & 940 \\
\hline WAS* $^{*}$ & $6(0.7)$ & $2(0.2)$ & $5(0.6)$ & $13(1.49)$ & 872 \\
\hline OR & 2.18 & 0.93 & 2.62 & $2.18+$ & \\
\hline $95 \% \mathrm{Cl}$ & 0.78 to 6.96 & 0.07 to 12.82 & 0.89 to 9.34 & 1.09 to 4.43 & \\
\hline Israeli Prostate Study & $14(1.49)$ & $2(0.21)$ & 14 (1.49) & $30(3.19)$ & 940 \\
\hline MECC $^{*}$ & $2(0.42)$ & $1(0.21)$ & $5(1.06)$ & $8(1.69)$ & 472 \\
\hline OR & 3.55 & 1.00 & 1.41 & 1.91 & \\
\hline $95 \% \mathrm{Cl}$ & 0.80 to 15.70 & 0.09 to 11.1 & 0.50 to 3.94 & 0.87 to 4.20 & \\
\hline Israeli Prostate Study & $14(1.49)$ & $2(0.21)$ & $14(1.49)$ & $30(3.19)$ & 940 \\
\hline WAS+MECC ${ }^{*}$ & $8(0.59)$ & $3(0.22)$ & $10(0.74)$ & $21(1.56)$ & 1344 \\
\hline OR & 2.52 & 0.22 & 2.02 & $2.08 \dagger$ & \\
\hline $95 \% \mathrm{Cl}$ & 1.05 to 6.04 & 0.16 to 5.72 & 0.16 to 5.72 & 0.16 to 5.72 & \\
\hline
\end{tabular}

Mutation carriers and non-carriers were comparable with respect to all the histological characteristics evaluated. While prostate cancer among carriers was more likely to arise in the setting of chronic prostatitis and to be associated with neuroendocrine features than was prostate cancer in noncarriers, these findings were not statistically significant. No significant differences were noted in either the mean primary or secondary Gleason grades or in the Gleason sum (table 2).

A number of case series have examined the carrier frequency among Ashkenazi men with prostate cancer ${ }^{4-6}$ (table 3). While the numbers of mutation carriers included in these studies have been very small, these studies have not suggested a large increase in prostate cancer risk associated with founder mutations. One small case-control study of Israeli prostate cancer cases and matched controls did not suggest an increased carrier frequency among cases, but provide a suggestion of a more aggressive phenotype among mutation carriers.

Two larger studies have estimated risk of prostate cancer indirectly, based on the history of prostate cancer in relatives of founder mutation carriers and non-carriers. ${ }^{12}$ Struewing and colleagues used a kin cohort analytic approach to estimate the cumulative incidence of cancer associated with Ashkenazi founder mutations in a study of over 5000 American Ashkenazi Jewish volunteers from the Washington DC area [the Washington Ashkenazi Study (WAS) ]. ${ }^{1}$ In this study, the founder mutations were found at a similar frequency to that reported in previous studies of Ashkenazi Jews. The risk of prostate cancer by 70 years of age was estimated to be $16 \%$ (95\% CI $4 \%-30 \%$ ) among male carriers of any founder mutation, compared with $3.8 \%$ among non-carriers $(95 \%$ CI $3.3 \%-4.4 \%)$, a risk equal to that of

Table 2 Pathological features of Israeli prostate cancer cases by carrier status

\begin{tabular}{|c|c|c|c|c|c|c|c|}
\hline \multirow[b]{2}{*}{ Pathology characteristic } & \multicolumn{2}{|c|}{ Carriers } & \multicolumn{2}{|c|}{ Non-carriers } & \multirow[b]{2}{*}{ OR } & \multirow[b]{2}{*}{$95 \% \mathrm{Cl}$} & \multirow[b]{2}{*}{$\mathbf{p}$} \\
\hline & $n=29$ & (\%) & $n=145$ & $(\%)$ & & & \\
\hline \multicolumn{8}{|l|}{ Benign and pre-neoplastic features } \\
\hline Atrophy & 3 & 10 & 11 & 8 & 1.40 & $0.32-5.0$ & 0.72 \\
\hline Benign prostatic hyperplasia & 5 & 16 & 19 & 13 & 1.43 & $0.45-4.2$ & 0.76 \\
\hline Chronic prostatitis & 9 & 31 & 23 & 16 & 2.47 & $0.93-6.4$ & 0.06 \\
\hline Basal cell hyperplasia & 1 & 3 & 10 & 7 & 0.44 & $0.02-3.3$ & 0.70 \\
\hline Atypical adenomatous hyperplasia & 0 & 0 & 2 & 1 & * & - & - \\
\hline Atypical small acini proliferation & 1 & 3 & 9 & 6 & 0.56 & $0.02-4.1$ & 0.69 \\
\hline \multicolumn{8}{|l|}{ Prostatic intraepithelial neoplasia } \\
\hline Low grade & 1 & 3 & 17 & 12 & 0.29 & $0.01-1.78$ & 0.32 \\
\hline High grade & 3 & 10 & 22 & 15 & 0.67 & $0.15-2.37$ & 0.57 \\
\hline Low or high grade & 4 & 14 & 38 & 26 & 0.49 & $0.13-1.39$ & 0.23 \\
\hline \multicolumn{8}{|l|}{ Adverse pathological features } \\
\hline Perineural invasion & 16 & 55 & 77 & 53 & 1.08 & $0.48-2.47$ & 1.00 \\
\hline Lymphovascular invasion & 0 & 0 & 5 & 3 & 0 & $0.00-4.8$ & 0.59 \\
\hline Neuroendocrine features & 6 & 21 & 13 & 9 & 2.7 & $0.88-8.1$ & 0.09 \\
\hline Extra prostatic extension & 3 & 10 & 6 & 4 & T & - & - \\
\hline Seminal vesicle involvement & 1 & 3 & 2 & 1 & $\dagger$ & - & - \\
\hline Any adverse feature & 21 & 72 & 95 & 66 & 1.40 & $0.54-3.5$ & 0.51 \\
\hline Mean Gleason Score & 7.1 & - & 7.0 & - & - & - & 0.70 \\
\hline
\end{tabular}

*Numbers too small for estimation of odds ratio

In the matched analysis, only five sets had both a case and at least one control that could be evaluated. Two of the cases, and none of the controls, had extra prostatic extension.

tln the matched analysis, only one set had both a case and a control that could be evaluated. The case had seminal vesicle involvement, but the control did not. 
Table 3 Risk of prostate cancer associated with BRCA1/2 Ashkenazi Jewish (AJ) founder mutations (literature review)

\begin{tabular}{|c|c|c|c|c|c|c|}
\hline \multirow[b]{3}{*}{ Study } & \multirow[b]{3}{*}{ Population } & \multicolumn{4}{|c|}{ Number $(\%)$ of individual subjects tested } & \multirow[b]{3}{*}{ Outcomes } \\
\hline & & \multirow[b]{2}{*}{$\mathbf{n}$} & \multicolumn{2}{|l|}{ BRCA1 } & \multirow{2}{*}{$\begin{array}{l}\text { BRCA2 } \\
6174 \text { delT }\end{array}$} & \\
\hline & & & 185delAG & 5382ins C & & \\
\hline \multicolumn{7}{|l|}{ Kin cohort } \\
\hline Struewing et $a l^{\prime}$ & $\begin{array}{l}\text { N. American AJ } \\
\text { volunteers; mutation } \\
\text { carriers and non- } \\
\text { carriers }\end{array}$ & 5318 & $41(0.8)$ & $20(0.4)$ & $59(1.2)$ & $\begin{array}{l}\text { Risk of prostate cancer by } 60 \text { and } 80 \text { years } \\
\text { of age among first degree relatives of } \\
\text { volunteers: with mutations } 16 \%, 39 \% \text {; } \\
\text { without mutations } 1 \%,<10 \% \text {, respectively }\end{array}$ \\
\hline Foulkes et $a l^{2}$ & $\begin{array}{l}\text { N. American AJ women } \\
\text { with breast cancer }\end{array}$ & 412 & $26(6.3)$ & $8(1.9)$ & $15(3.6)$ & $\begin{array}{l}\text { Risk of prostate cancer by the age of } \\
85 \text { years among first degree relatives of } \\
\text { Jewish breast cancer cases: with mutations } \\
34 \% \text {; without mutations } 13 \%\end{array}$ \\
\hline \multirow{3}{*}{$\begin{array}{l}\text { Case-control } \\
\text { Hubert et } a l^{3}\end{array}$} & & & & & & \\
\hline & $\begin{array}{l}\text { Unselected Israeli AJ } \\
\text { prostate cancer cases. }\end{array}$ & 87 & $2 / 87$ & & $1 / 87$ & $\begin{array}{l}\text { No difference in carrier frequency between } \\
\text { cases and controls. PSA and Gleason score }\end{array}$ \\
\hline & $\begin{array}{l}\text { Elderly Israeli AJ male } \\
\text { controls }\end{array}$ & 87 & $2 / 87$ & - & $1 / 87$ & $\begin{array}{l}\text { at diagnosis higher among carrier patients } \\
\text { than among non-carriers. Carrier cases } \\
\text { were more likely to have multiple primary } \\
\text { tumours }\end{array}$ \\
\hline $\begin{array}{l}\text { Case series } \\
\text { Lehrer et } a l^{4}\end{array}$ & $\begin{array}{l}\text { N. American AJ } \\
\text { prostate cancer } \\
\text { recruited from urology/ } \\
\text { radiation oncology clinics }\end{array}$ & 60 & $0 / 60$ & - & $0 / 60$ & No carriers identified \\
\hline Nastiuk et al ${ }^{5}$ & $\begin{array}{l}\text { N. American AJ with } \\
\text { prostate cancer; } \\
\text { pathology review. }\end{array}$ & 83 & $1(1.2)$ & - & $2(2.4)$ & $\begin{array}{l}\text { Carrier frequency not elevated compared } \\
\text { with population estimates }\end{array}$ \\
\hline Vazina et $a l^{6}$ & $\begin{array}{l}\text { Unselected Israeli AJ } \\
\text { men with prostate } \\
\text { cancer; pathology } \\
\text { review }\end{array}$ & 95 & $2 / 87(2.3)$ & $2 / 60(3.3)$ & $1 / 86(1.2)$ & $\begin{array}{l}\text { No mutation detected in any patient } \\
\text { diagnosed prior to the age of } 55 \text { years. } \\
\text { While reported as a negative study, the } \\
\text { results, when limited to the Ashkenazi } \\
\text { subset, appear consistent with an increased } \\
\text { risk among BRCAl mutation carriers } \\
\text { compared with population estimates. }\end{array}$ \\
\hline
\end{tabular}

ovarian cancer among female founder mutation carriers. The incidence of prostate cancer in carriers in the WAS was elevated by the age of 50 years, was statistically significantly elevated by 67 years, and increased thereafter with age, approaching $30 \%$ by 80 years, suggesting both an overall excess in prostate cancer risk, and an increased risk of early onset disease among founder mutation carriers. While confidence limits were widely overlapping in the WAS analysis, the risk of prostate cancer appeared higher among individuals with BRCA1 mutations than those with BRCA2 mutations, and there was some suggestion of early onset disease among those with a BRCAI 5382insC mutation. In that study, the number of individuals with a family history of prostate cancer was 5/40 (12\%), 5/20 (25\%), 6/54 (11), 16/1 14 (14\%), and 364/4759 (8\%) for 185delAG, 5382insC, 6174delT, any mutation, and non-carriers, respectively. Compared with non-carriers, those with a BRCAI 5382insC mutation and those with any founder mutation were at significantly increased risk of $\operatorname{PrC}(\mathrm{p}<0.01)$.

Warner and colleagues studied the risk of breast, ovarian and other cancers in the first degree relatives of 412 Ashkenazi Jewish women with breast cancer unselected for age or family history, who elected to undergo mutation testing. $^{2}$ Among first degree relatives of carriers of any founder mutation, the risk of prostate cancer was estimated to be $34 \%$ by by the age of 85 years compared with $12.6 \%$ among non-carriers $(\mathrm{p}=.05)$. Interestingly, this study appeared to enrich for carriers of the BRCAl 185delAG mutation, despite the nearly equal frequencies of the BRCAI 185delAG and the BRCA2 6174delT mutations in the general Ashkenazi population. Only $15(3.6 \%)$ of breast cancer patients in this study carried a 6174delT mutation compared with $26(6.3 \%)$ patients who carried a 185delAG mutation, perhaps reflecting variable penetrance of these two mutations for breast cancer. Differences in subject ascertainment could account for the observed differences in the estimated risk of prostate cancer in these two studies.

In our population based series, 3.2\% of Israeli Ashkenazi men with an incident diagnosis of prostate cancer, unselected for family history of breast and/or ovarian cancer, carried an Ashkenazi founder mutation. No population controls were obtained as part of this study. This represents a major limitation of our study design. We have attempted to address this limitation though comparison with existing Ashkenazi groups for which age and sex specific estimates of the founder mutation rate are available, i.e., the WAS and the MECC.

The MECC data are derived from a population based study of Israeli men and, while relatively small, is the best available Israeli comparison group. There is no statistical difference in the mutation frequency among participants in the MECC (1.69\%), which may over-represent Ashkenazi Jews immigrating from the former Soviet Union, and in that observed in the WAS $(1.49 \%)$, composed predominantly of immigrants from Germany, Poland and Austria. Estimates of the Ashkenazi BRCA founder mutation prevalence have been reported for several populations. These rates are strikingly similar across Ashkenazi populations living in various geographical regions. ${ }^{17814}$ We therefore thought it reasonable to combine the data from the MECC and WAS studies.

In the current study, we did observe an overall twofold risk of prostate cancer among founder mutation carriers. 
While increased risk of prostate cancer among carriers of the BRCA1 185delAG and the BRCA2 6174delT mutations appeared to be comparable (within the constraints of small numbers), only the estimate for the all mutations combined achieved statistical significance $(\mathrm{p}<0.05)$. No increased risk was associated with the 5382 ins $C$ mutation in this study. The mean age at diagnosis among BRCAl mutation carriers did not differ significantly from that of the BRCA2 mutation carriers, and neither differed significantly from the age at diagnosis among non-carriers. We found no evidence in this study to suggest an earlier than usual age of diagnosis in $B R C A$ associated prostate cancer.

Interestingly, data from both the WAS and the MECC suggest that the BRCA founder mutation prevalence rate may decrease with age. This would suggest that employing the overall $B R C A$ founder mutation frequency of approximately $2.4 \%^{78141}$ as the comparison, rather than an age specific prevalence estimate, will result in an underestimation of the risk of prostate cancer. If one takes into account a possible decline in founder mutation prevalence with age, our findings are consistent with at most a 2-4 fold increase in the risk of prostate cancer among carriers of an Ashkenazi $B R C A$ founder mutation.

Differences in the reported mutation specific risks probably represent statistical fluctuation related to small sample sizes. While a well designed, population based case-control study testing the hypotheses we explore here would be desirable, a study sufficiently powered to detect mutation specific risks is probably unfeasible. To detect reliably (with a power of 90\%) an odds ratio of 1.5 for the separate mutations 185delA, 5382 insC, and 6174delT, one would need total sample sizes of approximately 25000,100000 and 25000 respectively, assuming equal numbers of cases and controls. However, there would be little clinical interest in such small odds ratios, as risks at this level would result in a very low population attributable risk (\%), (calculated by 100.P.OR/ $(\mathrm{P} . \mathrm{OR}+\mathrm{l}-\mathrm{P})$, where $\mathrm{P}=$ prevalence of mutation in the general population and $\mathrm{OR}=$ odds ratio) associated with $B R C A$ founder mutation status. In our study, $\mathrm{P}=0.0156$ and $\mathrm{OR}=2.08$, so that the population attributable risk $=3.2 \%$. Thus, although the relative risk of prostate cancer among carriers of BRCA Ashkenazi Jewish founder mutations is significantly elevated, founder mutations explain only a small percentage of all prostate cancers occurring among Ashkenazi men. In view of the moderately high incidence of prostate cancer among Ashkenazi Jews, the absolute number of cases attributable to the founder mutations is not inconsequential, but alternative aetiological explanations must be sought for the majority of prostate cancers.

This study represents the largest reported series of $B R C A$ related prostate cancer to have undergone detailed, blinded histopathological review. Only one study to date has examined the clinical characteristics of prostate cancer diagnosed in Ashkenazi mutation carriers. In a small casecontrol study of Israeli Ashkenazi Jewish men with prostate cancer, Hubert and colleagues reviewed the pathology of three BRCA associated prostate cancers (two patients with BRCA1 185delAG mutations and one patient with a BRCA2 6174delT mutation). They suggested that these tumours appeared to be associated with biologically more aggressive disease. These cancers presented with higher PSA levels, higher Gleason scores and more advanced stage at diagnosis than did prostate cancers diagnosed in men without mutations. ${ }^{3}$

While data on initial stage and PSA at diagnosis were not available in our study, we found no evidence for distinctive clinical or pathological features among prostate cancer cases associated with an Ashkenazi founder mutation compared with prostate cancers occurring among non-carriers. It is interesting to note that the majority of carriers were diagnosed by needle biopsy rather than at prostatectomy. We have insufficient information to address the basis for this association. We selected prostate cancer cases diagnosed from 1994-1995, a time period antedating the widespread use of PSA screening in Israel. Therefore, we believe it unlikely that a detection bias due to differential PSA screening among men with a family history of breast and/or ovarian cancer could account for this association. Some clustering of chronic prostatitis was noted among cases with mutations, which may suggest a predilection for BRCA associated prostate cancers to arise in this setting. We did not find a higher Gleason Score among mutation positive cases.

In summary, our findings are consistent with previous reports of a modest increase in the risk of prostate cancer associated with the Ashkenazi founder mutations. This risk is unlikely to exceed a fourfold increase. This level of risk may warrant consideration of male carriers of Ashkenazi founder mutations as candidates for inclusion in high risk prostate cancer screening and/or risk reduction studies. Our review of the pathological characteristics of founder mutation $B R C A$ associated prostate cancer, while based on a relatively small number of cases, does not suggest that these cases display a more aggressive phenotype.

\section{Authors' affiliations}

R M Giusti, M H Greene, Clinical Genetics Branch, Division of Cancer Epidemiology and Genetics, National Cancer Institute (NCI), Bethesda, MD, USA

J L Rutter, J P Struewing, Laboratory of Population Genetics, Center for Cancer Research, National Cancer Institute, Bethesda, MD, USA

P H Duray, R D Ronchetti, S M Hewitt, Laboratory of Pathology, Center for Cancer Research, National Cancer Institute (NCI), Bethesda, MD

L S Freedman, Department of Mathematics, Statistics and Computer Science, Bar llan University, Ramat Gan, Israel

M Konichezky, Department of Pathology, Rabin Medical Center, Beilinson Campus, Petah Tikva, Israel

J Fisher-Fischbein, B Maslansky, The International Fertility Institute, Ra'anana, Israel

A Fischbein, * J Iscovich, Selikoff Center for Environmental Health and Human Development, Ra'anana, Israel

S B Gruber, Division of Medical Genetics, University of Michigan, Ann Arbor, MI

G Rennert, Department of Community Medicine and Epidemiology, Carmel Medical Center, Haifa, Israel

*A complete list of the working group members is provided in the Appendix.

Correspondence to: Dr R Giusti, Clinical Genetics Branch, Division of Cancer Epidemiology and Genetics, National Cancer Institute, NIH, DHHS, Executive Plaza South, Room 7024, 6120 Executive Boulevard, MSC 7231, Rockville, MD 20852-7231, USA; giusti@mail.nih.gov

Members of the Israeli BRCA Prostate Cancer Working Group The following are the contributing centers and the names of the pathologists contributing cases included in this analysis: I Avinoach MD, Wolfson Medical Center, Holon; E Felldberg, Kaplan Medical Center, Rehovot; E Goldshtein MD, Soroka Medical Center, Beer Sheba; G Grossman MD, Hillel Jaffe Medical Center, Hadera; I Kohen MD, West Galil Medical Center, Nahariya; M Konichezky MD, Rabin Medical Center, Beilinson Campus, Petah Tikva; S Lew MD, Meir Medical Center, Kfar Saba; B Lifschitz-Mercer MD, Tel Aviv-Jaffo Ichilov Medical Center, Tel-Aviv; I Mislevich MD, Bnei Zion Medical Center, Haifa; M Munichor MD, Rambam Medical Center, Haifa; M Resnick MD, Carmel Medical Center, Haifa; A Rozenman MD, Sharei Tzedek Medical Center, Jerusalem; I Sapir MD, Emek Medical Center, Afula; S Szvald MD, Zieff Medical Center, Zefat; A Tchernobilsky MD, PathoLab, Rehovot. 


\section{REFERENCES}

1 Struewing JP, Hartge P, Wacholder S, Baker SM, Berlin M, McAdams M, Timmerman MM, Brody LC, Tucker MA. The risk of cancer associated with specific mutations of BRCA1 and BRCA2 among Ashkenazi Jews. NEngl J Med 1997:336:1401-8.

2 Foulkes WD, Brunet JS, Warner E, Goodwin PJ, Meschino W, Narod SA, Goss PE, Glendon G. Prevalence and penetrance of BRCA1 and BRCA2 gene mutations in unselected Ashkenazi Jewish women with breast cancer. J Natl Cancer Inst 1999;91:1241-7.

3 Hubert A, Peretz T, Manor O, Kaduri L, Wienberg N, Lerer I, Sagi M, Abeliovich D. The Jewish Ashkenazi founder mutations in the BRCA1/BRCA2 genes are not found at an increased frequency in Ashkenazi patients with prostate cancer. Am J Hum Genet 1999:65:921-4.

4 Lehrer S, Fodor F, Stock RG, Stone NN, Eng C, Song HK, McGovern M. Absence of 185delAG mutation of the BRCA1 gene and 6174delT mutation of the BRCA2 gene in Ashkenazi Jewish men with prostate cancer. Br J Cancer 1998;78:771-3.

5 Nastiuk KL, Mansukhani M, Terry MB, Kularatne P, Rubin MA, Melamed J Gammon MD, Ittmann M, Krolewski J. Common mutations in BRCA1 and BRCA2 do not contribute to early prostate cancer in Jewish men. Prostate 1999;40:172-7.

6 Vazina A, Baniel J, Yaacobi Y, Shtriker A, Engelstein D, Leibovitz I, Zehavi M, Sidi AA, Ramon Y, Tischler T, Livne PM, Friedman $E$. The rate of the founder Jewish mutations in BRCA1 and BRCA2 in prostate cancer patients in Israel. Br J Cancer 2000;83:463-6.

7 Abeliovich D, Kaduri L, Lerer I, Weinberg N, Amir G, Sagi M, Zlotogora J, Heching $N$, Peretz $T$. The founder mutations 185delAG and 5382ins $C$ in BRCA1 and 6174 delT in BRCA2 appear in $60 \%$ of ovarian cancer and $30 \%$ of early-onset breast cancer patients among Ashkenazi women. Am J Hum Genet 1997;60:505-14.

8 Bahar AY, Taylor PJ, Andrews L, Proos A, Burnett L, Tucker K, Friedlander M Buckley MF. The frequency of founder mutations in the BRCA1, BRCA2, and APC genes in Australian Ashkenazi Jews: implications for the generality of U.S. population data. Cancer 2001;92:440-5.

9 Lubensky IA, Schmidt L, Zhuang Z, Weirich G, Pack S, Zambrano N, Walther MM, Choyke P, Linehan WM, Zbar B. Hereditary and sporadic papillary renal carcinomas with c-met mutations share a distinct morphological phenotype. Am J Pathol 1999;155:517-26.

10 Zambrano NR, Lubensky IA, Merino MJ, Linehan WM, Walther MM. Histopathology and molecular genetics of renal tumors: toward unification of a classification system. J Urol 1999;162:1246-58.

11 Gruber SB, Ellis NA, Scott KK, Almog R, Kolachana P, Bonner JD, Kirchhoff T, Tomsho LP, Nafa K, Pierce H, Low M, Satagopan J, Rennert H, Huang H, Greenson JK, Groden J, Rapaport B, Shia J, Johnson S, Gregersen PK, Harris CC, Boyd J, Offit K. BLM heterozygosity and the risk of colorecta cancer. Science 2002;297:2013.

12 Struewing JP, Coriaty ZM, Ron E, Livoff A, Konichezky M, Cohen P, Resnick MB, Lifzchiz-Mercerl B, Lew S, Iscovich J. Founder BRCA1/2 mutations among male patients with breast cancer in Israel. Am J Hum Genet 1999;65:1800-2.

13 Cuzick J. A method for analysing case-control studies with ordinal exposure variables. Biometrics 1985;41:609-21.

14 Struewing JP, Abeliovich D, Peretz T, Avishai N, Kaback MM, Collins FS, Brody LC. The carrier frequency of the BRCA1 185delAG mutation is approximately 1 percent in Ashkenazi Jewish individuals. Nat Genet 1995; 11:198-200.

\section{$\mathrm{ECHO}$}

\section{Genotype-phenotype analysis of the Crohn's disease susceptibility haplotype on chromosome 5q31}

\section{A Armuzzi, T Ahmad, K-L Ling, A de Silva, S Cullen, D van Heel, T R Orchard, K I Welsh, S E Marshall, D P Jewell}

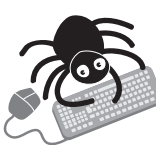

Please visit the Journal of Medical Genetics website [www. imedgenet. com] for a link to the full text of this article.
Background and aims: Recent molecular data suggest that genetic factors may underlie the disease heterogeneity observed in both ulcerative colitis (UC) and Crohn's disease (CD). A locus on chromosome $5 \mathrm{q}$ has been implicated in susceptibility to $\mathrm{CD}$, and recently refined by linkage disequilibrium mapping to a conserved $250 \mathrm{~kb}$ haplotype (5q31). No data regarding the contribution of this locus to clinical phenotype exist. In this case control study, we investigated the contribution of this haplotype to both susceptibility and phenotype of CD and UC.

Patients and methods: We studied 330 Caucasian CD and 457 UC patients recruited from a single UK centre. Association with disease susceptibility and phenotype was analysed with haplotypes reconstructed from three single nucleotide polymorphisms chosen to span this susceptibility region. Evidence for possible genetic epistasis between IBD5 and NOD2/ CARD15 was sought.

Results: Linkage disequilibrium across this region was confirmed, with two haplotypes comprising $88 \%$ of all chromosomes. Susceptibility to CD, but not to UC, was associated with homozygosity for a common haplotype, $\mathrm{H} 2\left(\mathrm{p}_{\mathrm{c}}=0.002\right.$; relative risk (RR) 2.0). Genotypephenotype analyses demonstrated that this association was particularly strong in patients with perianal disease $\left(p_{c}=0.0005\right.$; RR 1.7$)$, especially in individuals homozygous for this haplotype $\left(p_{c}=0.0005 ; R R 3.0\right)$. Importantly, no association with $\mathrm{H} 2$ was found in 186 patients without perianal disease. No evidence of epistasis between IBD5 and NOD2/ CARD15 was demonstrated.

Conclusions: The IBD5 risk haplotype is associated with CD only. Genotype-phenotype analysis reveals that the strongest association is observed in patients with perianal CD. While the precise gene involved is unclear, these data provide further molecular evidence for a genetic basis of the clinical heterogeneity of CD.

A Gut 2003;52:1133-1139. 


\title{
Congo red, doxycycline, and HSP70 overexpression reduce aggregate formation and cell death in cell models of oculopharyngeal muscular dystrophy
}

\author{
Y P Bao, S Sarkar, E Uyama, D C Rubinsztein
}

J Med Genet 2004;41:47-51. doi: 10.1136/jmg.2003.014548

$\mathrm{T}$ he formation of intracellular amyloid-like inclusions by mutant proteins is a feature of two groups of codon reiteration diseases, for which there are currently no treatments. The first group that was described includes the nine known neurodegenerative conditions caused by polyglutamine (polyQ) repeat expansions resulting from CAG trinucleotide repeat mutations, exemplified by Huntington's disease (HD). ${ }^{1}$ HD is caused by a tract of more than 37 uninterrupted polyglutamines in exon 1 of the HD gene product, huntingtin. Genetic and transgenic studies are consistent with a model where expanded polyglutamines cause disease by conferring a novel toxic function on the disease proteins. ${ }^{1-3}$

The second type of codon reiteration mutation results in autosomal dominant oculopharyngeal muscular dystrophy (OPMD). ${ }^{4}$ OPMD is caused by the abnormal expansion of a $(\mathrm{GCG})_{\mathrm{n}}$ trinucleotide repeat in the coding region of the polyadenine binding protein 2 gene $(P A B P 2)$ : a $(G C G)_{6}$ repeat is expanded to $(G C G)_{8-13}$ in most patients. In some rare cases, insertion mutations such as $(\mathrm{GCG})_{6} \mathrm{GCA}(\mathrm{GCG})_{2}$, $(\mathrm{GCG})_{6} \mathrm{GCA}(\mathrm{GCG})_{3}$ and $(\mathrm{GCG})_{6}(\mathrm{GCA})_{3}(\mathrm{GCG})_{2}$ are seen. ${ }^{56}$ In $P A B P 2,(G C G)_{6}$ codes for the first six alanines in a homopolymeric stretch of 10 alanines. Thus, disease is associated with expansions of 12 or more uninterrupted alanines in this nuclear protein. OPMD is characterised by aggregates in muscle cell nuclei comprising mutant PABP2 as a major component. ${ }^{4-9}$

The role of inclusions in these diseases has been vigorously disputed. ${ }^{1}$ Nevertheless, strategies that target protein misfolding frequently reduce aggregate formation and cell death in parallel. In mammalian cell based models of both polyglutamine and polyalanine diseases, the mutant proteins are much more prone to aggregate formation than their wildtype counterparts and cause significantly more cell death. ${ }^{111}$ In such models, aggregate formation and cell death can be reduced by overexpressing yeast and bacteria derived chaperones that do not appear to protect against some other cell death pathways. ${ }^{11-13}$ A causal role for aggregation in cell death in tissue culture models of OPMD is supported by complementary data from our lab and Rouleau's group. ${ }^{11}{ }^{14}$ Rouleau and colleagues found that oligomerisation of PABP2 is mediated by two potential oligomerisation domains (ODs)—deletions in either of these domains inactivated oligomerisation of mutant PABP2 and also reduced the cell death caused by this protein. ${ }^{14}$

The similarities between polyglutamine diseases and OPMD have led us to explore whether strategies that protect against polyglutamine aggregation or toxicity are also effective in OPMD models. Our previous studies suggested that mammalian heat shock proteins might be able to play similar roles in both diseases. ${ }^{11}{ }^{15}$ Members of the HSP70 and HSP40 family members are recruited to polyQ inclusions in vivo and in cell models. ${ }^{11}{ }^{15-21}$ We have tested

\section{Key points}

- Intracellular amyloid-like inclusions formed by mutant proteins result from polyglutamine expansions in Huntington's disease (HD) and polyalanine expansions in polyadenine binding protein 2 (PABP2) in oculopharyngeal muscular dystrophy (OPMD).

- Here we show further parallels between these diseases and suggest therapeutic strategies for OPMD. Like polyglutamine diseases, HSP70 and HDJ-1 colocalised with PABP2 aggregates in OPMD patient muscle tissue and overexpression of HSP70 reduced mutant PABP2 aggregate formation. Aggregate formation and cytotoxicity in cell models of OPMD were reduced by Congo red or doxycycline.

- Our data highlight the therapeutic potential of these compounds in oculopharyngeal muscular dystrophy.

if this is the case in OPMD patients, as we had previously shown that this occurred in a cell model of OPMD. ${ }^{11}$ We have previously shown that HDJl, an HSP40 family member, reduced aggregate formation and cell death in cell models of HD and OPMD. ${ }^{11}{ }^{15}$ Since HDJl is a co-chaperone for HSP70, we have now tested if HSP70 chaperone is effective in cell models of OPMD, as it can be effective in HD. ${ }^{15}$

Since it may be possible to treat these diseases with compounds that reduce aggregate formation, we have been testing a number of anti-amyloid compounds in cell based models of OPMD (where no animal models have been published). We tested Congo red, as data from Ross and colleagues suggested that it blocked the conversion of mutant huntingtin protofibrils into mature fibrils ${ }^{22}$ and Sanchez et al showed that Congo red reduced aggregation and cell death in HD cell models. ${ }^{23}$ The latter study also reported that infusion of Congo red into an HD mouse model by the intraperitoneal and intracerebroventricular routes improved survival, weight loss, and motor function, compared with untreated mutant mice. ${ }^{23}$ These data provided important insights into the role of inclusions polyglutamine disease pathology and suggested that the beneficial effects of Congo red were due to its

Abbreviations: DAPI, 4', 6-diamidino-2-phenylindole; DMEM, Dulbecco's modified Eagle's medium; Dox, doxycycline hydrochloride; EGFP, enhanced green fluorescent protein; GFP, green fluorescent protein; HD, Huntington's disease; HSP, heat shock protein; OD, oligomerisation domain; OPMD, oculopharyngeal muscular dystrophy; PABP2, polyadenine binding protein 2; polyQ, polyglutamine 
anti-aggregate properties. Unfortunately, the therapeutic potential for Congo red in HD may be minimal, because of its very poor blood brain barrier permeability. ${ }^{24}$ On the other hand, brain penetrance would not be an issue for a muscle disease like OPMD. We also tested doxycycline as an antiaggregate compound, since previous studies had suggested that tetracyclines were anti-amyloidogenic. ${ }^{25}$

\section{MATERIALS AND METHODS}

\section{Cell culture and transfection}

African green monkey kidney (COS-7) cells were grown in Dulbecco's modified Eagle's medium (DMEM 5471) (Sigma) supplemented with $10 \%$ fetal bovine serum, 100 units $/ \mathrm{ml}$ penicillin/streptomycin, and $2 \mathrm{mM} \mathrm{L}$-glutamine at $37^{\circ} \mathrm{C}, 5 \%$ $\mathrm{CO}_{2}$. For transfection of plasmid DNA, cells were seeded on coverslips at $0.6-1 \times 10^{5}$ per well, in 6-well plates, the day before transfection. Cells were transfected with Lipofectamine (Life Technologies) according to the manufacturer's instructions. Constructs are described in refs 11 (PABP2) and 15 (HSP70).

\section{Compounds and treatment}

Congo red (Sigma) was dissolved in DMEM 5671(Sigma) with a stock concentration of $10 \mathrm{mg} / \mathrm{ml}$. Doxycycline hydrochloride (Dox) (Sigma) was dissolved in water with a stock concentration of $100 \mathrm{mg} / \mathrm{ml}$. All the stock solutions were sterilised through a filter with a $0.2 \mu \mathrm{M}$ pore diameter. The compounds were diluted to the required concentration in the cell culture medium immediately before use. At $24 \mathrm{~h}$ after transfection, the compounds were added to the cells at different concentrations. The cells were incubated with the compounds for another $24 \mathrm{~h}$ and then washed with $1 \times$ phosphate buffered saline, fixed in $4 \%$ paraformaldehyde for $20 \mathrm{~min}$, mounted in antifadent reagent supplemented with $3 \mu \mathrm{g} / \mathrm{ml}$ of $4^{\prime}$, 6-diamidino-2-phenylindole (DAPI) to allow visualisation of nuclear morphology.

\section{Western blotting analysis}

Cells were lysed with Laemmli buffer $(0.0625 \mathrm{M}$ Tris- $\mathrm{HCl}$, pH 6.8, 2\% SDS, 5\% $\beta$-Mercaptoethanol, 10\% Glycerol, 0.01\% Bromophenol Blue). Lysates were subjected to SDS-polyacrylamide gel $(10 \%)$ electrophoresis and transferred to a nitrocellulose membrane (Amersham Pharmacia Biotech, UK). The membrane was incubated with mouse polyclonal anti-HSP70 (StressGene, 1:1000), mouse polyclonal antiHDJ-1 (StressGene, 1:1000) and rabbit anti-actin (Sigma, 1:2000), respectively. Blots were then incubated with peroxidase conjugated antimouse or antirabbit IgG antibody (Amersham Pharmacia Biotech, 1:1000). The proteins were detected using the enhanced chemiluminescence reagent (Amersham Phamacia Biotech). Protein loading was corrected by reprobing blots for actin.

\section{Immunohistochemistry}

Studies on human muscle samples were performed with the approval of ethics committees in Cambridge and Kumamoto. We have analysed frozen tissue sections from a muscle biopsy of the right sternohyoideus from an OPMD patient (female, 62 years old, with a 15 polyalanine expansion mutation in the PABP2 gene (genotype: $\left.(G C G)_{11} /(G C G)_{6}\right)$ ), the right gastrocnemius muscle from a patient (female, 61 years old, 15 polyalanines in PABP2; (genotype: $\left.(\mathrm{GCG})_{11} /(\mathrm{GCG})_{6}\right)$, the right deltoid muscle from a normal control ( 20 years old) and the right biceps muscle from a patient with dentatorubral pallidoluysian atrophy (non-OPMD disease control, male, 62 years old). The sections were fixed in $4 \%$ paraformaldehyde fixative for $10 \mathrm{~min}$ and then blocked with $5 \%$ horse serum for 1h. The colocalisation of endogenous PABP2 with HSP70, or PABP2 with HSP40 was detected by using the rabbit polyclonal anti-PABP2 antibody ${ }^{26}$ (1:200, kindly provided by Professor Elmar Wahle, Halle, Germany) together with the monoclonal mouse anti-HSP70 (1:200), or by using antiPABP2 antibody together with the monoclonal mouse antiHDJ-1 (1:200). The sections were then incubated with the mixture of antirabbit Texas red conjugated goat IgG antibody (Molecular probes, USA) and antimouse FITC conjugated goat IgG antibody (Alexa Fluor G488, Molecular probes, USA).

\section{Confocal microscopy}

Fluorescently labelled samples were analysed using the laser scanning microscope Zeiss LSM410 equipped with an argon ion laser (wavelength, $488 \mathrm{~nm}$ ) to excite FITC fluorescence, and a helium neon laser (wavelength, $543 \mathrm{~nm}$ ) to excite Texas red fluorescence. For double labelling experiments, images from the same focal plane were sequentially recorded in different channels and merged to confirm colocalisation.

\section{Measurement of aggregate formation and abnormal cell nuclei}

Cells were fixed with $4 \%$ paraformaldehyde at $72 \mathrm{~h}$ after transfection and counterstained with DAPI. Aggregate formation and nuclear morphology were assessed with a fluorescence microscope. Two hundred enhanced green fluorescent protein (EGFP) expressing cells were counted (with the observer blinded to the slide identity) across the centre region of the slides, to quantify all types of polyalanine aggregates in the cells. We assessed the proportions of PABP2-A17 expressing cells that contained one or more inclusions. We considered cells to have inclusions if the green fluorescent protein (GFP) was abnormally concentrated and differed from the nuclear speckled appearance typically seen with the normal PABP2-A10. Cells were considered dead if the DAPI-stained nuclei showed apoptotic morphology (fragmentation or pyknosis). Pyknotic nuclei are typically $<50 \%$ diameter of normal nuclei and show obvious increased DAPI intensity. We have demonstrated that these criteria are specific for cell death, as they show a very high correlation with propodium iodide staining in live cells. ${ }^{15}$

\section{Statistical analysis}

As we and others have described previously, ${ }^{10-13}$ pooled estimates for the changes in inclusion formation resulting from perturbations assessed in multiple experiments were calculated as odds ratios with $95 \%$ confidence intervals:

$$
\left(\begin{array}{c}
\% \text { cells expressing construct with inclusions } \\
\text { in perturbation conditions }
\end{array}\right)
$$

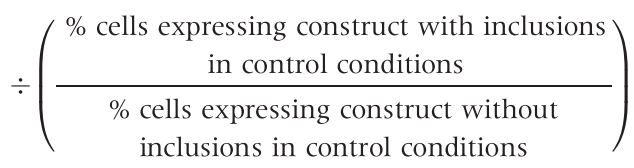

Odds ratios and p values were determined by unconditional logistical regression analysis using the general log/ linear analysis option of SPSS ver 6.1 software (SPSS, Chicago, USA). $\mathrm{p}<0.05$ was considered to be statistically significant.

\section{RESULTS}

To test if the intranuclear inclusions in OPMD patients sequester heat shock proteins (HSPs) in a manner similar to what we described in cell models, we used double staining 


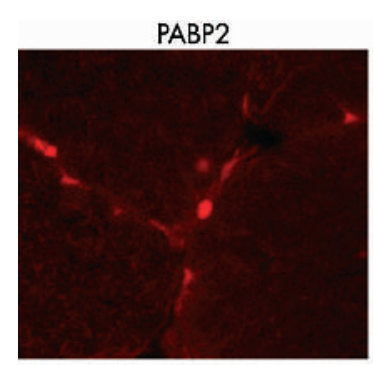

PABP2

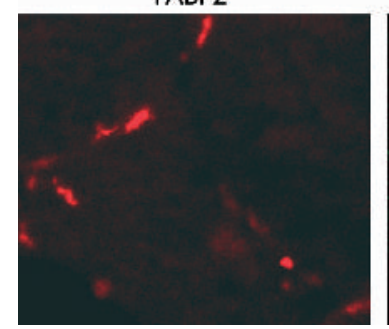

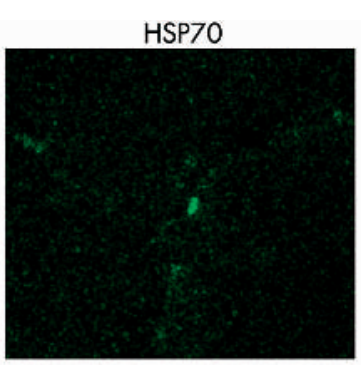

HDJ-1

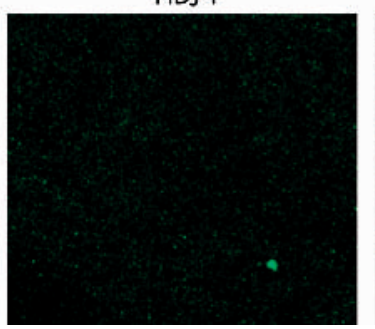

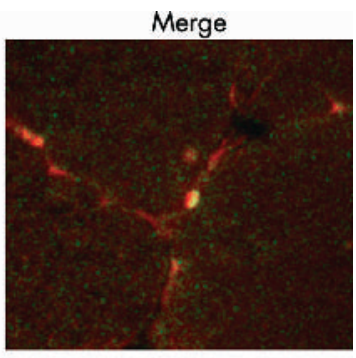

Merge

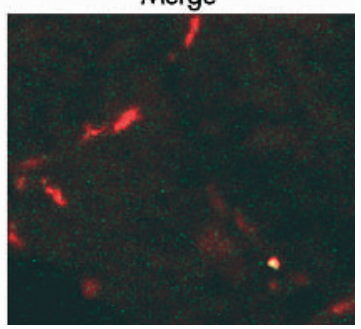

Figure 1 Colocalisation of HSP70 and HDJ-1 with nuclear PABP2 inclusions in muscle biopsies from OPMD patients. Frozen sections of muscle biopsies from OPMD patients were processed for immunohistochemistry. Texas red conjugated (red) second antibody was used to label PABP2 and FITC conjugated (green) secondary antibody was used to label HSP70 and HDJ-1. Colocalisation was confirmed by analysing images from the same focal plane sequentially recorded in different channels by confocal microscopy.

immunohistochemistry to allow simultaneous analysis of both mutant PABP2 and the relevant HSPs. Fig 1 shows colocalisation of HSP70 and HDJ-1 (HSP40 family) in inclusions in the DAPI stained nuclei of OPMD muscle. Similar findings were observed in samples from two OPMD patients. No colocalisation of these HSPs with PABP2 was seen in two control muscle samples (data not shown). The anti-PABP2 antibody we have used ${ }^{26}$ has been previously used to distinguish between cells with and without PABP2 aggregates. ${ }^{9}{ }^{14}$. The strong nuclear staining for the chaperones correlated strongly with the cells with nuclear aggregates (fig 1).

Previously, we showed that GFP tagged mutant PABP2 with 17 alanines (PABP2-A17) resulted in increased intranuclear aggregate formation and cell death, compared with otherwise identical constructs with 10 alanines ${ }^{11}$. HSP70 co-expression with GFP tagged mutant PABP2 with 17 alanines (PABP2-A17) significantly reduced the proportion of GFP positive cells with aggregates, compared with cells cotransfected with an empty vector control (pFlag-empty) (fig 2). HSP70 overexpression reduced the toxicity of mutant PABP2 in parallel with the reduction in aggregates (fig 2). Fig 2B shows that total HSP70 levels increase in cells transfected with HSP70, or in cells treated with sodium arsenite, which induces a heat shock response (as a positive control).

We considered Congo red and doxycycline as chemical chaperones with the potential to reduce mutant PABP2 aggregation and toxicity. COS-7 cells (the only cell model that has been reported to show aggregation and cell death as a readout for mutant OPMD toxicity) were transfected with GFP-tagged mutant PABP2 with 17 alanines (PABP2-A17). Twenty four hours after transfection, we added different concentrations of Congo red and doxycycline for the next $24 \mathrm{~h}$ and then assessed the proportions of GFP positive cells with aggregates and cell death (as scored by apoptotic nuclear morphology). We found that both Congo red and doxycycline reduced aggregation and cell death caused by mutant PABP2 (fig 3A). These effects were not caused by these compounds inducing raised levels of stress inducible HSPs, like HSP70 (fig 3B). While Congo red did not protect against cell death caused by incubating cells in staurosporine $(2.5 \mu \mathrm{M})$ or $\mathrm{H}_{2} \mathrm{O}_{2}(400 \mu \mathrm{M})^{11}$, protective effects were observed with doxycycline (fig 3C). In these experiments,

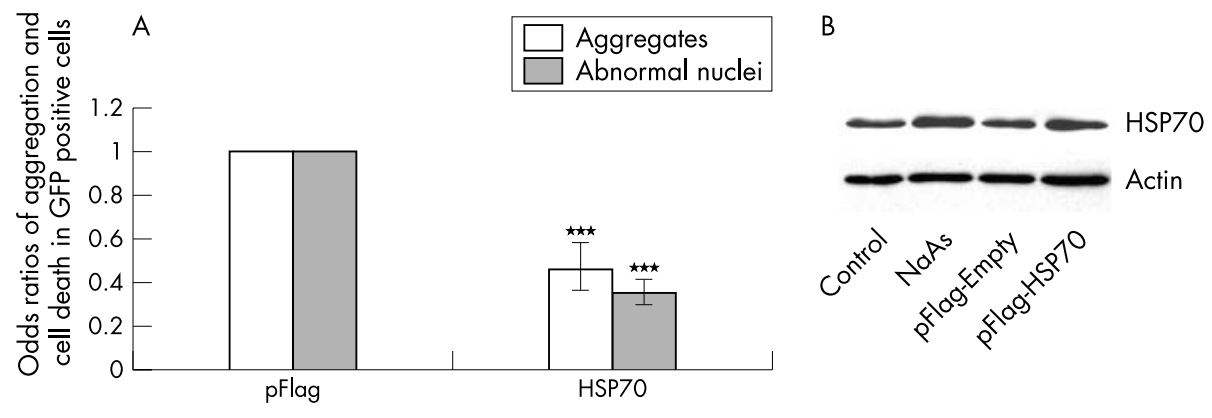

Figure 2 HSP70 overexpression suppresses aggregation of PABP2-A17 and its cytotoxicity. (A), PABP2-A17 (0.5 $\mu \mathrm{g})$ was cotransfected with an expression vector for HSP70 (pFlag-HSP70, $1.5 \mu \mathrm{g}$ ) or an empty vector (pFlag-empty, $1.5 \mu \mathrm{g}$ ). Cells were fixed and stained with DAPI $72 \mathrm{~h}$ after transfection. Aggregate formation and nuclear fragmentation/condensation were counted. The odds ratios were derived from $2-4$ independent experiments, each done in triplicate. The error bars represent the $95 \%$ confidence intervals for the odds ratios. ${ }^{*} p<0.05 ;{ }^{* *} p p<0.001 ;{ }^{* * *} p<0.0001$; not significant, $p>0.05$. (B), Western blot showing expression of HSP70 in transfected COS-7 cells. COS-7 cells were either transfected with $2 \mu \mathrm{g}$ PABP2-A17, treated or non-treated with sodium arsenate $\left(\mathrm{NaAsO}_{2}, 50 \mu \mathrm{M}\right.$, treated for $\left.1 \mathrm{~h}\right)$ or cotransfected with PABP2-A17 (0.5 $\left.\mu \mathrm{g}\right)$ and pFlagHSP70 $(1.5 \mu \mathrm{g})$, PABP2-A17 and pFlag-empty $(1.5 \mu \mathrm{g})$. NaAsO 2 was used as a positive control to stimulate HSP70 expression. 

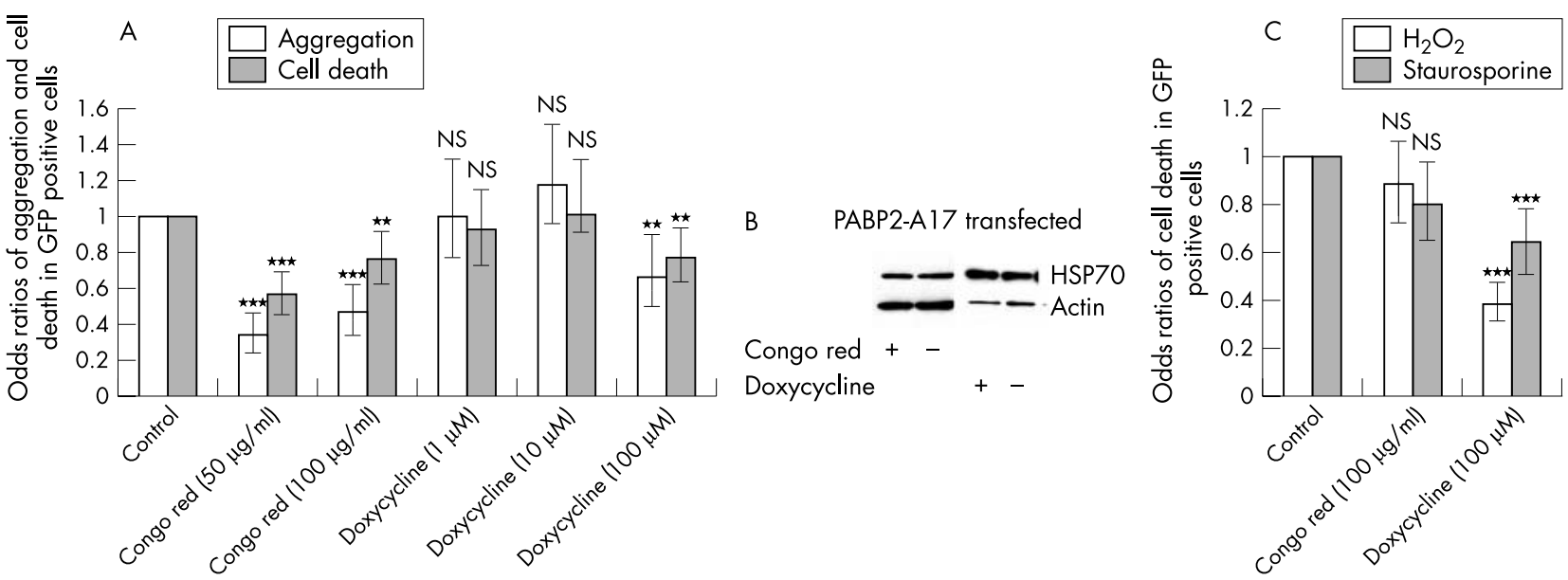

Figure 3 Congo red and doxycycline (Dox) reduce aggregation and cell death in cell models of OPMD and HD. (A) COS-7 cells were transfected with PABP2-A17. Congo red or Dox with different doses were added $24 \mathrm{~h}$ after transfection. Cells were incubated with the compounds for another $24 \mathrm{~h}$ and then fixed and stained with DAPI. The proportions of cells with aggregates and nuclear fragmentation or condensation were determined. The odds ratios were derived from 2-4 independent experiments, each done in triplicate. The error bars represent the $95 \%$ confidence intervals for the odds ratios. ${ }^{*} p<0.05 ;{ }^{* *} p<0.001$; ${ }^{* * *} p<0.0001$; not significant, $\mathrm{p}>0.05$. The $95 \%$ confidence intervals for $50 \mu \mathrm{g} / \mathrm{ml}$ and $100 \mu \mathrm{g} / \mathrm{ml}$ Congo red overlap, suggesting that there are no significant differences between these doses. (B) Congo red and Dox do not stimulate the expression of HSP70. COS7 cells were transfected with PABP2-A17. $100 \mu \mathrm{g} / \mathrm{ml}$ of Congo red or $100 \mu \mathrm{M}$ of Dox was added to the cells $24 \mathrm{~h}$ after transfection. Cells were harvested after another $24 \mathrm{~h}$, Western blotting was carried out, and the expression level of HSP7O was detected. (C) Effects of Congo red (100 $\mu \mathrm{g} / \mathrm{ml}$ ) and Dox $(100 \mu \mathrm{M})$ on cell death caused by pro-apoptotic agents. COS-7 cells were transfected with the vector pEGFP-Cl and the Congo red and doxycycline were added $24 \mathrm{~h}$ after transfection. After another $24 \mathrm{~h}$, either $\mathrm{H}_{2} \mathrm{O}_{2}$ or Staurosporine were added to the cells (for $4 \mathrm{~h}$ and $6 \mathrm{~h}$, respectively) before fixing the cells. Nuclear fragmentation and condensation were determined in GFP positive cells. The odds ratios were derived from 2-4 independent experiments, each done in triplicate. The error bars represent the $95 \%$ confidence intervals for the odds ratios. ${ }^{*} p<0.05 ;{ }^{* *} p<0.001 ;{ }^{* * *} p<0.0001$; not significant, $\mathrm{p}>0.05$.

cells were treated in the same protocol as described previously ${ }^{11}$, and staurosporine and $\mathrm{H}_{2} \mathrm{O}_{2}$ were added in the final $6 \mathrm{~h}$ and $4 \mathrm{~h}$, respectively, of the experiment.

\section{Discussion}

Both polyglutamine diseases like HD and polyalanine expansion mutations in PABP2 are associated with intracellular inclusions, whose appearance correlates with cell death in model systems. In this study we have extended the parallels between these different types of codon reiteration mutations by demonstrating HSP70 and HDJ-1 colocalisation in PABP2 inclusions in vivo, which has been previously observed in HD and related polyglutamine diseases ${ }^{15-21}$. The failure to detect colocalisation of these HSPs with PABP2 in wild-type samples or outside the nucleus in OPMD tissues is likely to be because the HSP preferentially associate with the aggregated protein and because PABP2 is predominantly nuclear in steady state. HSP70 overexpression resulted in a reduction of mutant $\mathrm{PABP} 2$ and $\mathrm{HD}$ exon $\mathrm{I}^{15}$ aggregation and cytotoxicity. While this paper was being written, Abu-Baker et al published data also showing colocalisation of HSP70 with OPMD aggregates and reduction of these aggregates with overexpression of this chaperone. ${ }^{27}$ Since HSP70 can directly protect against certain apoptotic pathways, for instance by inhibiting cytochrome c-mediated caspase activation, ${ }^{28}{ }^{29}$ it is important to be cautious about inferring a causal relationship between reduced aggregation and cell death in this context. Indeed, this cell death pathway is activated and contributes to the cytotoxicity in HD cell models. ${ }^{15}$

The reduction in aggregation and cell death mediated by Congo red and doxycycline against mutant PABP2 suggests that these compounds may have therapeutic potential, especially for OPMD. The concentrations that we have used are compatible with previous studies in HD models. We obtained significant reductions in aggregation and cell death caused by mutant PABP2 with $50 \mu \mathrm{g} / \mathrm{ml}(70 \mu \mathrm{M})$ Congo red, while Sanchez and colleagues reported reduction in their HD cell models with $100 \mu \mathrm{M} .^{23}$ Recently, Smith et al reported that doxycycline reduced aggregation in a slice culture model of HD at $30 \mu \mathrm{M},{ }^{30}$ while we observed protection in our OPMD model with $100 \mu \mathrm{M}$. Doxycycline appears to be protective by reducing aggregation and also by reducing susceptibility to cell death pathways induced by apoptotic inducers like staurosporine and $\mathrm{H}_{2} \mathrm{O}_{2}$, the latter effect compatible with the data of Chen et al who showed minocycline reduced caspase activation in a mouse model of HD. ${ }^{31}$ However, since tetracyclines are predicted to protect against apoptosis by inhibiting caspases and caspase 1 is interleukin- $1 \beta$-converting enzyme, the effects of tetracyclines may also be due to anti-inflammatory activity in certain in vivo disease models. While Congo red may have limited utility in HD due to its poor blood brain barrier permeability, ${ }^{24}$ it may be useful for diseases associated with aggregation outside the central nervous system, such as OPMD. Congo red appears to be a general amyloid protein ligand. ${ }^{31}$ In the case of HD, it blocks the conversion of protofibril to mature fibre formation in the aggregation process. ${ }^{22}$ Modelling studies reveal that Congo red is likely to break the continuity of the ordered structures of the $\beta$-sheets characteristic of polyalanine expansions, ${ }^{32} 33$ thus providing a molecular explanation for the effect we observed with the mutant PABP2 protein. The parallel protection that Congo red affords against the cytotocity of expanded polyglutamines and polyalanines is consistent with the idea that abnormal protein aggregation and accumulation may be deleterious in all intracellular amyloidoses, irrespective of the primary mutation.

\section{ACKNOWLEDGEMENTS}

We thank Professor Elmar Wahle (Halle, Germany) for the supply of anti-PABP2 antibody.

\section{Authors' affiliations}

Y P Bao, S Sarkar, D C Rubinsztein, Department of Medical Genetics, Cambridge Institute for Medical Research, Wellcome/MRC Building, Addenbrooke's Hospital, Hills Road, Cambridge, CB2 2XY, United Kingdom 
E Uyama, Department of Neurology, Kumamoto University School of Medicine, 1-1-1-Honjo, Kumamoto, 860-0811, Japan

This work was funded by the Muscular Dystrophy Campaign (UK), the MRC (Programme grant to DCR and Professor Steve Brown) and Grantsin-Aid for Scientific Research (EU) for funding. We are grateful for a Wellcome Trust Senior Fellowship in Clinical Science (DCR) and a Gates Cambridge Scholarship (SS).

Correspondence to: D C Rubinsztein; dcr1000@cus.cam.ac.uk

Received 16 September 2003

In revised form 13 October 2003

Accepted 14 October 2003

\section{REFERENCES}

1 Rubinsztein DC. Lessons from animal models of Huntington's disease. Trends Genet, 2002; 18:202-9.

2 Lunkes A, Lindenberg KS, Ben-Haiem L, Weber C, Devys D,

Landwehrmeyer GB, Mandel JL, Trottier Y. Proteases acting on mutant huntingtin generate cleaved products that differentially build up cytoplasmic and nuclear inclusions. Mol Cell 2002; 10:259-69.

3 Wellington CL, Ellerby LM, Gutekunst CA, Rogers D, Warby S, Graham RK, Loubser O, van Raamsdonk J, Singaraja R, Yang YZ, Gafni J, Bredesen D, Hersch SM, Leavitt BR, Roy S, Nicholson DW, Hayden MR. Caspase cleavage of mutant huntingtin precedes neurodegeneration in Huntington's disease. J Neurosci 2002;22:7862-72.

4 Brais B, Bouchard JP, Xie YG, Rochefort DL, Chretien N, Tome FM, Lafreniere RG, Rommens JM, Uyama E, Nohira O, Blumen S, Korczyn AD, Heutink P, Mathieu J, Duranceau A, Codere F, Fardeau M, Rouleau GA, Korcyn AD. Short GCG expansions in the PABP2 gene cause oculopharyngeal muscular dystrophy. Nat Genet 1998;18:164-7.

5 Scacheri PC, Garcia C, Hebert R, Hoffman EP. Unique PABP2 mutations in "Cajuns" suggest multiple founders of oculopharyngeal muscular dystrophy in populations with French ancestry. Am J Med Genet 1999;86:477-81.

6 Nakamoto M, Nakano S, Kawashima S, Ihara M, Nishimura Y, Shinde A, Kakizuka A. Unequal crossing-over in unique PABP2 mutations in Japanese patients: a possible cause of oculopharyngeal muscular dystrophy. Arch Neurol 2002;59:474-7.

7 Tome FM, Chateau D, Helbling-Leclerc A, Fardeau M. Morphological changes in muscle fibers in oculopharyngeal muscular dystrophy. Neuromuscul Disord 1997;7(Suppl 1):S63-9.

8 Uyama E, Tsukahara T, Goto K, Kurano Y, Ogawa M, Kim YJ, Uchino M, Arahata K. Nuclear accumulation of expanded PABP2 gene product in oculopharyngeal muscular dystrophy. Muscle Nerve 2000;23:1549-54.

9 Calado A, Tome FM, Brais B, Rouleau GA, Kuhn U, Wahle E, CarmoFonseca $M$. Nuclear inclusions in oculopharyngeal muscular dystrophy consist of poly (A) binding protein 2 aggregates which sequester poly(A) RNA. Hum Mol Genet 2000;9:2321-8.

10 Wyttenbach A, Carmichael J, Swartz J, Furlong R, Narain Y, Rankin J, Rubinsztein DC. Effects of heat shock, heat shock protein 40 (HDJ-2), and proteasome inhibition on protein aggregation in cellular models of Huntington's disease. Proc Natl Acad Sci U S A 2000:97:2898-903.

11 Bao YP, Cook L, O'Donovan D, Uyama E, Rubinsztein DC. Mammalian, yeast, bacterial, and chemical chaperones reduce aggregate formation and death in a cell model of oculopharyngeal muscular dystrophy. J Biol Chem 2002;277:12263-9.

12 Carmichael J, Chatellier J, Woolfson A, Milstein C, Fersht AR, Rubinsztein DC. Bacterial and yeast chaperones reduce both aggregate formation and cell death in mammalian cell models of Huntington's disease. Proc Natl Acad Sci U S A 2000;97:9701-5.

13 Carmichael J, Vacher C, Rubinsztein DC. The bacterial chaperonin GroEL requires GroES to reduce aggregation and cell death in a COS-7 cell model of Huntington's disease. Neurosci Lett 2002;330:270-4.
14 Shanmugam V, Dion P, Rochefort D, Laganiere J, Brais B, Rouleau GA. $\mathrm{PABP} 2$ polyalanine tract expansion causes intranuclear inclusions in oculopharyngeal muscular dystrophy. Ann Neurol 2000;48:798-802.

15 Wyttenbach A, Sauvageot O, Carmichael J, Diaz-Latoud C, Arrigo AP, Rubinsztein DC. Heat shock protein 27 prevents cellular polyglutamine toxicity and suppresses the increase of reactive oxygen species caused by huntingtin. Hum Mol Genet 2002;11:1137-51.

16 Wyttenbach A, Swartz J, Kita H, Thykjaer T, Carmichael J, Bradley J, Brown R, Maxwell M, Schapira A, Orntoft TF, Kato K, Rubinsztein DC. Polyglutamine expansions cause decreased CRE-mediated transcription and early gene expression changes prior to cell death in an inducible cell model of Huntington's disease. Hum Mol Genet 2001;10:1829-45.

17 Cummings CJ, Mancini MA, Antalffy B, DeFranco DB, Orr HT, Zoghbi HY. Chaperone suppression of aggregation and altered subcellular proteasome localization imply protein misfolding in SCA1. Nat Genet 1998;19:148-54.

18 Chai Y, Koppenhafer SL, Bonini NM, Paulson HL. Analysis of the role of heat shock protein (Hsp) molecular chaperones in polyglutamine disease. J Neurosci 1999; 19:10338-47.

19 Jana NR, Tanaka M, Wang GH, Nukina N. Polyglutamine length-dependent interaction of $\mathrm{Hsp} 40$ and $\mathrm{Hsp} 70$ family chaperones with truncated $\mathrm{N}$-terminal huntingtin: their role in suppression of aggregation and cellular toxicity. Hum Mol Genet 2000:9:2009-18.

20 Kobayashi Y, Kume A, Li M, Doyu M, Hata M, Ohtsuka K, Sobue G. Chaperones $\mathrm{Hsp70}$ and $\mathrm{Hsp} 40$ suppress aggregate formation and apoptosis in cultured neuronal cells expressing truncated androgen receptor protein with expanded polyglutamine tract. J Biol Chem 2000;275:8772-8.

21 Stenoien DL, Cummings CJ, Adams HP, Mancini MG, Patel K, DeMartino GN Marcelli M, Weigel NL, Mancini MA. Polyglutamine-expanded androgen receptors form aggregates that sequester heat shock proteins, proteasome components and SRC-1, and are suppressed by the HDJ-2 chaperone. Hum Mol Genet 1999;8:731-41.

22 Poirier MA, Li H, Macosko J, Cai S, Amzel M, Ross CA. Huntingtin spheroids and protofibrils as precursors in polyglutamine fibrilization. J Biol Chem 2002;277:41032-7.

23 Sanchez I, Mahlke C, Yuan J. Pivotal role of oligomerization in expanded polyglutamine neurodegenerative disorders. Nature 2003;421:373-9.

24 Lee VM. Amyloid binding ligands as Alzheimer's disease therapies. Neurobiol Aging 2002;23:1039-42.

25 Forloni G, Colombo L, Girola L, Tagliavini F, Salmona M. Anti-amyloidogenic activity of tetracyclines: studies in vitro. FEBS Lett 2001;487:404-7.

26 Krause S, Fakan S, Weis K, Wahle E. Immunodetection of poly(A)-binding protein II in the cell nucleus. Exp Cell Res 1994;214:75-82.

27 Abu-Baker A, Messaed C, Laganiere J, Gaspar C, Brais B, Rouleau GA Involvement of the ubiquitin-proteasome pathway and molecular chaperones in oculopharyngeal muscular dystrophy (OPMD). Hum Mol Genet 2003; 12:2609-23

28 Saleh A, Srinivasula SM, Balkir L, Robbins PD, Alnemri ES. Negative regulation of the Apaf-1 apoptosome by Hsp70. Nat Cell Biol 2000;2:476-83.

29 Beere HM, Wolf BB, Cain K, Mosser DD, Mahboubi A, Kuwana T, Tailor P, Morimoto RI, Cohen GM, Green DR. Heat-shock protein 70 inhibits apoptosis by preventing recruitment of procaspase- 9 to the Apaf-1 apoptosome. Nat Cell Biol 2000;2:469-75

30 Smith DL, Woodman B, Mahal A, Sathasivam K, Ghazi-Noori S, Lowden PA, Bates GP, Hockly E. Minocycline and doxycycline are not beneficial in a model of Huntington's disease. Ann Neurol 2003;54:186-96.

31 Chen M, Ona VO, Li M, Ferrante RJ, Fink KB, Zhu S, Bian J, Guo L, Farrell LA, Hersch SM, Hobbs W, Vonsattel JP, Cha JH, Friedlander RM. Minocycline inhibits caspase- 1 and caspase- 3 expression and delays mortality in a transgenic mouse model of Huntington disease. Nat Med 2000;6:797-801.

32 Roterman I, Krol M, Nowak M, Konieczny L, Rybarska J, Stopa B, Piekarska B Zemanek $G$. Why Congo red binding is specific for amyloid proteins-model studies and a computer analysis approach. Med Sci Monit 2001;7:771-84.

33 Blondelle SE, Forood B, Houghten RA, Perez-Paya E. Polyalanine-based peptides as models for self-associated beta-pleated-sheet complexes. Biochemistry 1997;36:8393-400.

\section{CORRECTION}

Giusti RM, Rutter JL, Duray PH, et al. J Med Genet 2003;40:787-792. During the production process errors were introduced into Table 1 of this paper. The odds ratio value for the BRCAl 5382insC mutation in the WAS + MECC studies should read 0.95 . The $95 \%$ CI for the BRCA2 6174delT and the total positive frequency should read 0.89-4.56 and $1.18-3.65$, respectively. 